\title{
The Foundation and Problems of Independent Colleges Participating in the Construction of Modern Vocational Education System
}

\author{
Hui Zhou \\ Xiamen Institute of Software Technology \\ Xiamen, China 361000
}

\author{
Yuchen Zheng* \\ Xiamen University Tankahkee College \\ Xiamen, China 361000 \\ *Corresponding Author
}

\begin{abstract}
In the modern vocational education system, the training of talents has the characteristics of application, development and life-long. These characteristics are inward and unanimously consistent with the orientation of the training and orientation of the independent college and the goal of development. From the practice of the classification theory of higher education and the participation of Independent Colleges in the construction of modern vocational education system, the active participation of Independent Colleges in the construction of modern vocational education system is not only the internal driving force of its own development, but also the requirement for the independent college to build a modern vocational education system in the context of the popularization of higher education.
\end{abstract}

Keywords-modern vocational education system; independent college; development path research

\section{INTRODUCTION}

In 2012 , the national medium and long term education reform and development outline proposed, "by 2020, a modern vocational education system should be formed to adapt to the transformation of the mode of economic development and the adjustment of industrial structure, the concept of lifelong education, and the coordinated development of secondary and higher vocational education". With this goal, the system design of modern vocational education system has entered the public view. For a time, schools with different school types are exploring and thinking about how to locate and how to participate in the construction of modern vocational education system. The independent college is the new thing which came into being under the background of the popularization of higher education in our country. The current state has vigorously constructed the modern vocational education system, making the independent college standing at the crossroads of the development again. Where should the independent college go? How to choose? Should we participate in construction or develop independently? The thinking of these problems is undoubtedly the strategic choice and characteristic orientation of these schools after realizing a new round of leapfrog development, which is related to their future development and positioning under the pattern of higher education in China.

\section{THE CHARACTERISTICS OF THE MODERN VOCATIONAL EDUCATION S YSTEM}

As for modern vocational education system, there are many misunderstandings in theory and cognition, narrowing the understanding of modern vocational education system. [1], at the same time, people who are bound by traditional thinking often regard the general education which pays attention to the education as the source of high quality education, and regard vocational education as incomplete and low level education. [2], therefore, combined with the national medium and long term development outline, the connotation of modern vocational education system is as follows:

\section{A. Modernity}

The proposition of modern vocational education system is relative to traditional vocational education, and modernity is its essential characteristic. There are many drawbacks in the traditional vocational education. For example, in the era of planned economy, the departments of the departments of running schools, industries, running schools and education departments have formed "fragmentation". After the fragmentation of the system has been broken, it is faced with the "level barrier" in the development. Moreover, the different levels of vocational education are difficult to connect and link up, the system mechanism is relatively solidified, lack of innovation and change. The speed of progress is slow and so on. The modernity of the modern vocational education system is that it emphasizes the continuous innovation, change and progress, overcome the difficult problems that the traditional vocational education can't overcome, and solve all kinds of "strip segmentation" and "level barrier" which restrict the healthy development of vocational education, and realize the connection and connection of the primary, middle and higher vocational education, and meet the diversified educational needs of the educated. [2] 


\section{B. Systematicness}

The systematicness of modern vocational education, that is, the level and structure of the design of the system of job teaching is more open and more complete. The basic content of the modern vocational education system and the two major components - the vocational school education and the vocational training are clarified. At the same time, especially strengthening the communication link between secondary vocational and vocational education, in order to dock industry and industry to different levels of professional talents, explore from basic to high-end multi-level professional training system, improve the ability of vocational education to serve the economic and social development, and support the national industrial competitiveness for the purpose of forming a scientific talent growth "cross bridge". The systematicness of the modern vocational education system is still open. In particular, the vocational education in the modern vocational education system must communicate with other types of the modern national education system, coordinate and develop each other, connect vertically and interconnect, and form a "relatively perfect modern national education system". [2]

\section{Openness}

The modern vocational education system embodies the concept of lifelong education. It emphasizes people oriented and pays attention to the all-round development of human beings. Premier Wen has repeatedly stressed that vocational education is oriented to all people and society oriented education, with professional, popular and sociality, and to make more people find space suitable for their own learning and development, to provide a variety of different ways of success and to meet the different educational needs of all people as far as possible. The traditional vocational education pays more attention to the second industry, especially the manufacturing industry, and neglects the demand for talent training and the characteristics of talent demand in other walks of life. The modern vocational education system pays close attention to the demands of the talents training and the characteristics of talent demand in all walks of life, and forms a new system of comprehensive, standardized and open vocational education and efficient and flexible operation mechanism of vocational education. To break the endogenous impetus of innovation, development and progress, to meet the needs of building a learning society for the whole people and lifelong learning, is helpful to the overall development of the society and the lifelong development of the people. [3]

Based on the above analysis, the modern vocational education system first is a national education type which is parallel to the national education system and has internal self-system. At the same time, training professional talents as the orientation to meet the demands of people's career growth at different stages of different objects, including educational education and on-the-job training, in the vertical, with professional development and technical progress, can continuously improve the vocational level, including secondary vocational, vocational, vocational undergraduate
(Higher Vocational Undergraduate), professional master's master, professional doctor.

\section{THE BASIS OF TRANSFORMATION AND DEVELOPMENT OF INDEPENDENT COLLEGES UNDER THE MODERN VOCATIONAL EDUCATION SYSTEM.}

Independent colleges are the inevitable outcome of diversified education in China under the wave of mass higher education in China, which meets the needs of society and people for higher education. An independent college with both public and private advantages has become an important force in China's higher education. At present, the state actively constructs the modern vocational education system, and undoubtedly pushes the independent college to a crossroads to reexamine its own development path. This article holds that the independent college actively participates in the construction of the modern vocational education system, which is not only the external driving force for the change of social transformation and the new task of the new period to the independent college, but also the internal drive for its own development and transformation. The main basis for independent colleges to participate in the construction of modern vocational education system is as follows:

\section{A. The Need to Improve the Modern Vocational Education System}

As far as our education structure system is concerned, general education is a relatively complete system -- high school, junior college, undergraduate course, master degree and doctor. But the vocational education system is a lack of structure, only the "broken head" system of secondary vocational and professional level or only "secondary vocational, vocational, professional master, professional doctorate" has no "undergraduate" fault education system. The imperfection of higher vocational education system has become the biggest obstacle to further development of higher vocational education.

The independent college is born under the background of insufficient investment in public higher education and the heavy responsibility of higher education, which bears the historical mission of cultivating applied talents. The traditional research university has the responsibility of cultivating the academic talents, taking on the important task of solving the national economic construction and social development. It is neither good at nor paying attention to the variety of vocational education training requirements. It often trains applied talents or professional needs according to the training mode of academic talents, which makes it difficult for students to adapt to the needs of post and the needs of continuing study. Higher vocational colleges have lower level of education and are hard to adapt to higher level training tasks. The independent college can give full play to the experience and mechanism of cultivating undergraduate applied talents, improve the level of vocational education, promote the vocational education system to advance in the independent college, and make its due contribution to the improvement of the vocational education system in China. 


\section{B. Adapt to Lifelong Education under the Background of Popularization}

With the diversification and diversification of the demand for talents, the traditional educational and diploma education has been gradually desalinated, and the pursuit of the promotion of human capital has been paid more and more attention. The concept of lifelong education will be accepted by more and more people. Therefore, a variety of learning patterns under the background of mass education, including academic education, short-term education, skill training, post training and so on, will develop coexisting among various schools or schools. (The theory and practice of the sustainable development strategy of independent colleges, 183) this popular education demand is not only satisfied by the ordinary universities and higher vocational colleges, and the diversified development of vocational education has the inevitable trend. The independent college actively participates in the construction of modern vocational education system, which can not only promote the combination of vocational education and educational education, but also strengthen vocational education. It is suitable for lifelong education under the background of popularization.

\section{The Demand for the Local Regional Economic Development}

For the purpose of setting up an independent college, the social and economic development of the service area is one of its important goals. Independent colleges face regional education and require active service for regional development. On the one hand, most independent colleges have relevant industry background, more understanding of related industries, industries and post groups, more familiar with the demand characteristics and development rules of industry and professional posts, and the development of high skilled personnel for the development of local economy. In addition, the upgrading of industrial upgrading and the upgrading of technological focus require high training focus of vocational skills. The independent college has a more broad vision and a systematic knowledge system than the higher vocational college, which has a stronger support for the development of local economy.

The independent colleges choose to participate in the construction of the modern vocational education system, realize the continuous vocational and technical personnel training system and serve the needs of local economy and social development, not only make the independent college get a wider space for survival and development, but also reflect the social service function and social value of the independent College as a regional university, and achieve the win-win of the interactive development of the school land.

\section{The Choice Based on Its Sustainable Development}

From the external ecological environment, the biggest dilemma in the development of independent colleges is the competitive pressure of the students. According to the 2011 Chinese education online survey report, the average enrollment ratio of the national college entrance examination has increased rapidly in the last 3 years. In the background of the decrease in the total population of the age population and the pluralistic development of education, the diversion and competition of the students are self-evident. In addition, from 2012, the eligible independent colleges will gradually issue academic certificates and degree certificates independently, and their social attractiveness will also be affected from two independent colleges that are completely divorced from the care of the parent institutions. The development of independent college in the initial stage of development, overreliance on the school experience of the parent school, is easy to fall into the model of homogeneity of development. At present, the independent college has ushered in the key moment of the second transformation and development. Under the new situation, the problems existing in the traditional undergraduate cultivation model of the independent college are reexamined and evaluated, and the modern vocational education system is constructed by actively participating in the construction of the modern vocational education system. To cultivate professional talents with distinctive characteristics and solid foundation can we highlight their characteristics and develop in the future.

\section{PROBLEMS AND THINKING}

From the reality of the current independent college, the vast majority of colleges and universities in the construction of modern vocational education are still in its infancy, there is no mature precedent for reference. Independent colleges should further clarify the basic ideas of transformation and development so as to identify the location and realize development in the modern vocational education system.

\section{A. Transformation and Development and Concept Renewal}

It is very sensitive and subtle to talk about Vocational Education in the current field of undergraduate education. Vocational education seems to be associated with secondary school and high school in the minds of people. Independent college is not generally willing to "downgrade" to the level of the cultivation of high-quality talents occupation ". This is a biased understanding of modern vocational education. In the current country, the modern vocational education system is actively constructed and the higher vocational education level moves up - further extending to the above level, the independent college should break through the traditional ideology and re understand the connotation of the open, systematic and life-long connotation of the modern vocational education, and actively participate in and construct the modern vocational education system, which is the important prerequisite for overcoming homogenized development with the parent university and realizing a new round of development.

\section{B. Transformation and Development and Talent Training}

"What kind of people to train and how to train people" is the primary consideration of the transformation and development of independent colleges and the construction of modern vocational education system. The transformation of independent colleges, if copying the training mode of higher vocational education, is bound to be unacceptable because of 
the difference of talent cultivation. The principle to solve this problem should be "guaranteed capital increase". It is to increase the connotation of vocational education at the same time of guaranteeing the level and specification of the undergraduate education, integrate the undergraduate education and vocational education, realize mutual penetration and mutual promotion, make the students of the independent college set up the theoretical knowledge, professional skills and professional accomplishment, that is "the high quality skilled talents of the undergraduate level", and the high quality embodies the school running of the independent college. At the level, the students have more solid theoretical knowledge and social practice ability and professionalism and innovative consciousness than the students in higher vocational colleges. The skill type embodies the independent college and the profession, focuses on the improvement of professional quality and professional skills, and improves the students' employability, so as to meet the needs of the economic and social transformation and upgrading. (Three perspectives for the transformation from independent colleges to higher vocational education)

\section{Transformation and Development and External Relations}

The transformation and development of independent colleges cannot be separated from the support of government policies. The government departments in charge of education, especially the educational departments and personnel and social security departments, should conscientiously study the structure, quantity and quality of the demand for professional talents in the local economic and social development, fully realize the urgency and importance of building a perfect vocational education system and actively encourage the development of higher vocational education at the undergraduate and above levels. Industry education, for the independent college that has the will to the transition to higher vocational education, can be used as a pilot and give policy support: first, the establishment of an independent development of higher vocational education expert group, periodic assessment of the development of Vocational Education in independent colleges, solve problems, summarize the experience, cultivate typical. The two is to give independent colleges for developing vocational education more autonomy and innovative development space, for example, independent colleges can adjust professional settings and training plans more flexibly according to their own development and social needs, and the independent colleges of higher vocational education have developed more successful and mature independent colleges to encourage the application of the application type graduate students. The three is to build a positive financial policy and give financial support to the transition from independent colleges to higher vocational education: to establish a diversified investment channel and investment system, to encourage the participation of social funds, and to set up the hard and soft conditions needed by the independent colleges to help the independent colleges to improve their careers. Four, we should actively introduce the training and funding system of international vocational education. For the independent college teachers to improve the application of professional skills, apply for teaching practical scientific research projects, professional title evaluation and appointment, enter the enterprises and institutions practice or study abroad to give help to the policy. [8]

\section{Transformation and Development and Path Selection}

When we actively build the choice of the independent college development path under the modern vocational education system, we have to admit that there are differences in the foundation, the school level and the development goal of the independent college. These differences also determine that the path selection of the independent college in the modern vocational education system can only be guided by the potential, but not the same. If all the independent colleges are confined to the modern vocational education system, it will be difficult to find their true characteristics, so that they will lose the motivation of sustainable development and the diversification of the future development of independent colleges.

\section{CONCLUSION}

In the modern vocational education system, talent cultivation has the features of application, development, and lifelong. These characteristics are intrinsically consistent with the independent training orientation and development goals of the independent college. The independent college of modern vocational education should consider the ideas of transformation and development and the concept of renewal talent cultivation, the ideas of transformation and development and external relations, and the ideas of transformation and development and path selection. And then, they would be able to seize opportunities and achieve leaps in the future development. Of course, the independent college, which has a clear idea of development and a good foundation for running a school, is likely to achieve the great goal of "high quality and first-class private university", which is comparable to that of the famous schools abroad, if it can develop into a comprehensive and high level university in the pattern of higher education. This is the promotion and promotion of the development of Chinese private colleges and universities as well as the overall reform of China's higher education. The test is also worth looking forward to. However, all path selection must be based on a clear judgment of the future development of higher education and its own development conditions.

\section{REFERENCES}

[1] Fan Wei, Guo Yang, Ma Shuchao. Explore the basic path of the construction of modern vocational education system. [J]., China higher education research, 2011, 12: 62-66..

[2] Zhang Zhenyuan. Analysis of the proposition of modern vocational education system, [J]. Vocational Education Forum, 2011, (28): 4-9.

[3] Ministry of education. Interpretation of establishing modern vocational education system.

[4] Pan Maoyuan, Chen Houfeng. Methodology of higher education classification. [J]. higher education research, 2006, 3 (9). 
[5] Wang Ling. Under the modern vocational education system, the orientation of applied undergraduate talents training is analyzed. [J]. vocational education technology, 2012, (25): 19-23..

[6] Wang Zhiqiang. Research on the development mode of independent college [M]. Chengdu: University of Electronic Science and Technology Press, 2011.

[7] Yan Liezhou, Li Xiaobo, Cao Yanfeng. The independent colleges to establish occupation education on [J]. 2012 (4): 24-26.

[8] He Xu. Transformation of independent colleges to higher occupation education three education from the perspective of $[\mathrm{J}]$. academic magazine, 2012, (1): 90-93. 